\title{
実用的なスポット像からの波面収差解析手法の開発*
}

\author{
上島正史*1, 天谷賢 治*2, 片 岡 康 生*3 $^{* 3}$
}

\section{Development of the Practical Aberration Retrieval Method from Spot Intensity Images}

\author{
Masashi UESHIMA, Kenji AMAYA*4 and Kosei KATAOKA \\ ${ }^{* 4}$ Department of Mechanical and Environmental Informatics, \\ Graduate School of Information Science and Engineering, Tokyo Institute of Technology, \\ 2-12-1 O-okayama, Meguro-ku, Tokyo, 152-8550 Japan
}

\begin{abstract}
Aberration retrieval is an important technology for evaluation of quality of imaging optics. In this study, a practical system that identifies the aberration of imaging optics from spot intensity images has been developed. The complex amplitude distribution of spot on defocus plane is expanded to Nijboer-Zernike series and neglect higher order terms. Then the identification problem is reduced to the non-linear optimization problem whose design variables are Nijboer-Zernike coefficients. This problem is solved by the quasi Newton method. In addition, some accuracy improvement techniques have been applied to this method. These techniques are summarized as follows. (1) The captured spot intensity images are filtered with low-pass filter whose cutoff frequency is decided from the numerical aperture of imaging optics. (2) The background level is taking account for numerical model of intensity image, and background level is also identified during the optimization process. Some numerical experiments and practical ones were performed to demonstrate the effectiveness of the present method. In addition, four kinds of practical experiment based on theories were performed, and all of these experiment got high correlation between input parameter and measurement result and high consistency with theoretical forecast. These results proved that this aberration retrieval method have enough capability to be used practically.
\end{abstract}

Key Words: Aberration Retrieval, Optical Measurement, Spot Intensity Image, Nijboer-Zernike Polynomial, Inverse Problem, Laser, Numerical Analysis, Image Processing

\section{1. 緒 言}

\section{1 -1 研究背景と目的顕微鏡用対物レンズや光} ピックアップなどの回折限界の性能が要求される結像 光学系の生産において, 集光性能評価, 寸なわち収 差解析を欠かすことはできない. 特に近年の光ピック アップはその高性能化から構成の複雑さが増してきて おり，製品の調整と品質管理のために収差を高精度に モニタリングしたいという要望が高まっている.

収差解析手法は，スポット像を平行光分布 $(\fallingdotseq$ 空間 スペクトル)に変換してから波面収差 (位相分布)を測 定する手法と，スポット像から直接収差解析を行う手 法の二種類に大別することができる.

* 原稿受付 2008 年 5 月 26 日.

*1 東京工業大学大学院情報理工学研究科情報環境学専攻 (ङ 152-8550 東京都目黒区大岡山 2-12-1)

*2 正員, 東京工業大学情報理工学研究科情報環境学専攻.

*3 (株)カツラ・オプト・システムズ(画215-0004 川崎市麻生 区万福寺 1-1-1)

E-mail : kamaya@a.mei.titech.ac.jp
前者の代表的な例として，干渉計により被測定光と 参照光との相対的な位相分布を求める方法 ${ }^{(1)}$ が挙げら れる.この手法は従来から信頼されており, 光学部品 の品質管理の基準として広く用いられている. しかし 干渉計は精密な光学機器で構成されているため, 装置 が高価である．また，装置の微調整を測定ごとに行う 必要があり，非効率である。

一方，スポット像から収差解析を行う手法で用いる 装置, 顕微鏡と $\mathrm{CCD}$ などの撮像素子を組み合わたもの と簡便な構成となる. 測定はこの装置を用いてスポッ 卜像を撮影するだけですみ，その為，干渉計より安価 であり，効率的な測定が可能である。これまでに，ス ポット像からの収差解析手法は多く提案されてきた. しかし，それらを実用的に用いるには様々な問題を含 んでいる. 現在, 光ピックアップの生産ライン上での 収差評価手法として実用的に用いられている手法は田 中らの開発した手法 ${ }^{(2)}$ のみである。この手法は三次収 
差と相関のある指標を積分計算を算出するのみである. しかし近年の光ピックアップの生産においては五次収 差成分の評価も不可欠である.

そこで本研究は, 従来のスポット像からの波面収差 解析研究を基礎として, 光ピックアップの生産ライン 上で実用的に用いることができるスポット像からの波 面収差解析手法の開発を目的とする.

1.2 スポット像からの収差解析手法の従来研究とそ の問題点 スポット像からの収差解析手法は収束型 と積分型の二種類に大別することができる.

収束型の代表的な手法としては R.W.Gerchberg らが 提案した位相回復法 ${ }^{(3)}$ が挙げられる.これは光の物理 的な Fourier 変換作用に注目し, 波面収差を収束計算 により同定する手法である。この他にも同様な研究例 は多い ${ }^{(4)(5)}$ 。また，収差関数を Zernike 級数 ${ }^{(6)}$ で展開 し，その係数を同定する問題とすることで，解析の安 定性と精度向上を行った研究も J.R.Fienupをはじめと して多くなされている(7)(8).

積分型の手法では先述の田中らの手法が挙げられる. 最近の研究では P.Dirksen らがデフォーカス面におけ る複素振幅分布を直接級数表現できる Nijboer-Zernike の基底関数 ${ }^{(6)}$ と測定したデフォーカス面のスポット像 との内積を積分計算することで収差係数を同定する手 法を開発している ${ }^{(9)}$.

スポット像からの波面收差手法を生産ライン上で実 用的に用いる場合, 以下に示寸三つの問題点を全て克 服している必要がある。

一点目仕計算精度と計算時間の両立である. 光ピッ クアップの生産においては $2[\mathrm{~m} \lambda]$ の精度での収差評価 を $1[\mathrm{sec}]$ 以内に行うことが望まれる. 収束型の手法は Fourier 変換や畳多込み積分を収束計算中に多数回行 う必要がある。これらの計算を精密に計算した場合， 波面収差同定に多くの時間を要し; 高速に解析するこ とが困難となる．高速 Fourier 変換老用いて計算時間 の短縮を図った場合，円形の空間スペクトルを直交に 離散化して計算する必要がある。この影響により，角 度方向の計算精度の劣化を招き, 収差の同定精度, 特 に円形の収差である球面収差の同定精度が著しく劣化 する. 積分型は収束型よりも高速に解析がすることが 可能であるが精度を確保することが難しい．てれは残 りの二つの問題点を克服していないからである.

二点目は空閒スペクトルの強度分布が任意の分布 であっても波面収差を正しく同定できるかという点 である. 過去の研究の多くは空間スペクトルの強度 分布は一様, もしくは既知という仮定を行い，波面 収差のみを末知数としている. 前述の R.W.Gerchberg
やJ.R.Fienup, P.Dirksen らの手法もこの仮定を含む. 実際の光ピックアップに用いられているレーザ光源の 強度分布は一様ではない，その分布も個々の光ピック アップにおいてばらつきがある，それ故に，上記の仮 定が同定精度の劣化を招く．また，純粋な顕微鏡では スポット像と空間スペクトルの強度分布を同時に测定 することは不可能であり，両者を同時に計測できる装 置の開発はコストがかかる.

三点目は $\mathrm{CCD}$ 等の撮像素子によって発生する各種 ノイズ対するロバスト性の問題である. CCDで測定し た画像にはブルーミングや量子化誤差, バックグラウ ンドレベルのオフセットなど様々なノイズが含まれて いる. スポット像には強度の強い領域と微弱な領域と が併存しているうえ，高次の収差成分になるほど強度 が微弱な領域への感度が高くなる.そのため, スポッ 卜像からの収差解析手法は一般的にノイズに対する口 バスト性が低い。この問題点は広く認識されてきた事 実であるが，これらのノイズ八の対策について論じた 研究例は見受けられない.

この様な背景により，上記の三点の問題点を全て克 服した高性能な手法の開発が望まれている.

1.3 本研究で開発する手法本研究では収束型 の収差解析手法を基礎とし，光ピックアップの生産ラ イン上で実用的に適用できる新しいスポット像からの 波面収差解析手法開発する。開発する手法は以下の ようにまとめられる。1）フォーカス面の空間スペク トルの実部と虚部をそれぞれ低次の有限個の Zernike 級数で展開する. そして本手法はそれらの展開係数を 求める非線形最小二乗問題とする，これにより，本手 法は収差と空間スペクトルの強度分布を同時に求め ることになる，2）スポット像の強度分布はNijboerZernike 級数を用いて計算する。これにより，収束計算 中に Fourier 変換や畳み込み積分を行われないことに なる．3）以下の二個の撮像素子ノイズ低減手法を適 用する. A）測定画像にローパスフィルタを用いた， イズ除去を適用する.そのカットオフ周波数は光学系 の開口数から決定する。 B ) 测定画像のモデルにバッ クグラウンドレベルのオフセットを考慮する.そして バックグラウンドレベルも本手法の未知量とする.

1.4 本論文の構成本論文ではまず本手法の概 要について述べる. 次に, 本手法の数值実験による結 果, ならびに実際の DVD ピックアップを解析した例 を示す．最後にDVDピックアップを用いた四種類の 収差変化実験を行い, 理論的予測と実験結果とを比較 した結果を示す。 


\section{2. 収差解析手法の原理}

$2 \cdot 1$ 問題設定結像側のフォーカス面における 複素振幅分布 ${ }^{(6)} \boldsymbol{g}$, それに対する任意のデフォーカ ス面の複素振幅分布を $f_{i}$ と表すものとする． $i$ はデ フォーカス面に対する添え字とする．また，波面収差 を $\phi$ とする，これらの間で成立する関係式は以下のよ うに示すことができる。

$$
\begin{aligned}
& g^{*}(u, \psi)=\left|g^{*}(u, \psi)\right| \cdot \exp (i 2 \pi \phi(u, \psi)) \\
& f_{i}^{*}(u, \psi)=h_{i}(u) \cdot g^{*}(u, \psi)
\end{aligned}
$$

ここで， $g^{*} ， f_{i}^{*}$ はそれぞれ $g, f_{i}$ の空間スペクトルと する.また， $(u, \psi)$ は空間周波数の極座標系とする. $u$ は空間周波数の次元を最大空閒周波数 $\left(=\frac{\mathrm{NA}}{\lambda}, \mathrm{NA}\right.$ 開口数， $\lambda$ は波長) で正規化した無次元量とする。式 (2) の光伝播を表す式は厳密に Helmholtz 方程式を満 足する角度スペクトル伝播モデル(10)である， $h_{i}(u)$ は 次式で与えられる.

$$
h_{i}(u)=\exp \left(i 2 \pi \frac{D_{i}}{\lambda} \sqrt{1-(\mathrm{NA} u)^{2}}\right)
$$

ここで， $D_{i}$ は $f_{i}$ のデフォーカス距離を表す.

ベクトル $\boldsymbol{v}$ の離散表現を $\{\boldsymbol{v}\}$ とし，\{v\}の絶対值の 分布 (振幅分布) $|\{\boldsymbol{v}\}|$, 絶対值の二乗の分布 (強度分 布)を $|\{\boldsymbol{v}\}|^{2}$ ，と書くものとする。この時， $\mathrm{CCD} よ ゙$ で撮影したデフォーカス面の離散強度分布を $\left|\left\{\overline{f_{i}}\right\}\right|^{2}$ とすると，次式の関係が得られる。

$$
\left|\left\{f_{i}\right\}\right|^{2}=\left|\left\{\overline{f_{i}}\right\}\right|^{2}
$$

本問題では以上の関係式と観測量 $\left|\left\{\overline{f_{i}}\right\}\right|^{2}$ よりフォー カス面の空間スペクトル $\boldsymbol{g}^{*}$ を同定する。これは，波

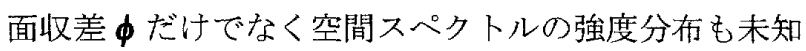
数と設定していることと同義である.

2.2 Nijboer-Zernike 理論によるデフォーカス面の モデル化 Zernike 釉数 ${ }^{(6)}$ は次式の変数分離形で与 えられる。

$$
R_{n}^{m}(u, \psi)=U_{n}^{m}(u) V^{m}(\psi)
$$

ここで， $U_{n}^{m}$ は半径方向項， $V^{m}$ が角度方向項， $m, n$ はそれぞれ角度方向，半径方向への次元に相当する值 である。

フォーカス面の空閒スペクトル分布 $\boldsymbol{g}^{*}$ はZernike 級 数を用いて次式で表せる.

$$
g^{*}(u, \psi)=\sum_{n, m}^{\infty}\left(i \alpha_{n}^{m}+\beta_{n}^{m}\right) R_{n}^{m}(u, \psi)
$$

上式と式(2)より，次式が得られる.

$$
f^{*}(u, \psi)=\sum_{n, m}^{\infty}\left(i \alpha_{n}^{m}+\beta_{n}^{m}\right) h(u) R_{n}^{m}(u, \psi)
$$

上式の Fourier 変換である $\boldsymbol{f}$ は Nijboerにより次式で 表されることが示されている.

$$
\begin{gathered}
f(r, \theta)=\sum_{n, m}^{\infty}\left(i \alpha_{n}^{m}+\beta_{n}^{m}\right) A_{n}^{m}(r, \theta) \\
A_{n}^{m}(r, \theta)=\int_{0}^{1} 2 \pi i^{m} J_{m}\left(2 \pi \frac{\mathrm{NA}}{\lambda} u r\right) h(u) U_{n}^{m}(u) V^{m}(\theta) u d u
\end{gathered}
$$

$\alpha_{n}^{m}$ 亡 $\beta_{n}^{m}$ 低次の係数を並べたベクトルを $\{K\}$, それに 対応する $i A_{n}^{m}(r, \theta), A_{n}^{m}(r, \theta)$ を並べて離散表現したも のを $[\boldsymbol{A}]$ とすれば，式(8) の離散表現は次式で表せる.

$$
\{f\}=[\boldsymbol{A}]\{K\}
$$

$2 \cdot 3$ 解析手法 観測方程式 (4) および式 (10) よ り，フォーカス面の空間スペクトル $\boldsymbol{g}^{*}$ を表す低次の 係数を求める逆問題を無制約最適化問題として定式化 する.すなわち，設計変数を $\{K\}$ とし，次式のような 非線形の評価関数を設定する.

$$
\sum_{i}\left\|\left[W_{i}\right]\left(\left|\left[A_{i}\right]\{K\}\right|^{2}-\left|\left\{\overline{f_{i}}\right\}\right|^{2}\right)\right\|^{2} \rightarrow \min
$$

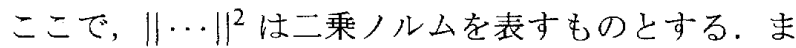


非線形最適化手法を用いて評価関数の最小化を行うこ とで $\{K\}$ を求める. 最後に, 求めた $\{K\}$, すなわち $\alpha_{n}^{m}$ と $\beta_{n}^{m}$ より次式の方程式を最小二乗法などを用い て解くことで波面収差係数 $z_{k}$ を求める.

$$
\sum_{k} z_{k} R_{k}(u, \psi)=\operatorname{Arg}\left(\sum_{n, m}\left(i \alpha_{n}^{m}+\beta_{n}^{m}\right) R_{n}^{m}(u, \psi)\right)
$$

ここで， $k$ は $n, m$ の組み合わせを適当な順番に並べた 添え字とする. 収差計数 $z_{k}$ は FringeZernike 倸数 ${ }^{(12)}$ と して定められた順番に並心゙るのが一般的である. $z_{k}$ の $m, n$ との対応例を表 1 に示す. 以下, 本論文でも $z_{k}$ は この順番に並べられているものとする。

本手法では式 (8) で表される Nijboer-Zernike の基底 関数を用いている.これを離散化したマトリックス $\left[A_{i}\right]$ は収束計算を行う前に精度良く計算・作成することが できる. 特に， $\theta$ 方向の積分は解析的に行われている ため， $\theta$ 方向の精度劣化はほぼ皆無である。

また，スポット像の離散点数を $n$ とした場合，従 来研究で高速 Fourier 変換を用いた場合の計算量は $O\left(n \log _{2} n\right)$ となるのに対し, 本手法は $O(n)$ の計算量 であるため, 収束計算中に Fourier 変換や畳み込み積 分の演算を要する従来研究よりも高速な解析が可能と なる. 実際の問題での $n$ は 1600 ほどとなるので，概 算で 10 倍以上の計算の効率化がなされている. 
評価関数を BFGS 法などで解く際には勾配の計算 が必要となる。これは通常多くの計算量を要すが，評 価関数を計算する際に途中の計算結果を保存するこ とで計算量を減らせる，また，本手法は行列演算が多 く、計算の並列化をできる部分が多いため, $\mathrm{BLAS}^{(13)}$ や $\mathrm{LAPACK}^{(14)}$ などの線形計算ライブラリを利用し， OpenMP ${ }^{(15)}$ などで計算を積極的に並列化することで計 算速度は格段に向上する。

過去のスポット像からの位相回復問題研究において, 正しく位相分布を求めるにはフォ一カス面を挟んだ二 枚のデフォーカス面の強度分布を用いることが最低限 必要であることが議論されている，本手法において もそれは例外では無く，正しく収差解析を行うには正 負二枚のデフォーカス面のスポット像を用いる必要が ある。

Table 1 Correspondence of Fringe Zernike coefficient and parameter $n, m$

\begin{tabular}{c|c|c|c|c|c|c|c|c|c|c|c} 
& $z_{0}$ & $z_{1}$ & $z_{2}$ & $z_{3}$ & $z_{4}$ & $z_{5}$ & $z_{6}$ & $z_{7}$ & $z_{8}$ & $z_{9}$ & $z_{10}$ \\
\hline$n$ & 0 & 1 & 1 & 2 & 2 & 2 & 3 & 3 & 4 & 3 & 3 \\
$m$ & 0 & 1 & -1 & 0 & 2 & -2 & 1 & -1 & 0 & 3 & -3
\end{tabular}

\section{4 撮像素子の各種ノイズに対するロバスト性を} 向上させるための改良

2.4.1 測定したスポット像へのローパスフィルタと カットオフ周波数の設定法 $\mathrm{CCD}$ などの撮像素子 を用いてデジタル画像解析を行う場合，測定した画像 には高周波な信号ノイズや階調誤差を多く含む、その ため，測定画像に何かしらのフィルタリングを施すこ とが考えられるが，スポット像を撮影対象とした場合 にはローパスフィルタが最も効果的である.

ローパスフィルタを用いる場合, 適切なカットオフ 周波数を設定する必要がある。ここで，スポット像に 含まれる最大空間周波数は $v_{\max }=2 \frac{\mathrm{NA}}{\lambda}$ であるので(16)， $v_{\text {max }}$ をカットオフ周波数としてローパスフィルタを施 すことにより，測定したスポット像の高周波ノイズと スポットの物理情報を合理的に分離し，ノイズを除去 することができる。

例えば，像のピクセル数が $512 \times 512 ， 1$ ピクセルの スポット面での実寸が $15[\mathrm{~nm}]$, 波長が $650[\mathrm{~nm}], N A$ が 0.6 とした場合，フィルタリングは半径 30[pixel] 程 度の円形領域内部のみを残す様にすればよく，大半の 高周波成分を除去することができる。

本ローパスフィルタの本手法に対する直接的な効果 は主に二点ある。一点目は高次の波面収差成分同定の 精度と安定性の向上である。図 1 は実際に8bit の CCD で撮影した DVD ピックアップのスポット像に対して
本ローパスフィルタを適用した例である，収差解析に おいて実際に評価対象となるのは $z_{4}$ 以降の収差成分 であるが，これらの成分がスポット像に影響を与える 領域は所謂一次リングの外側であり，図 1 上図の強度 7 以下の強度が微弱な領域となる。これらの領域の物 理情報を抽出できる本ローパスフィルタは波面収差同 定の精度と安定性の向上に大きく貢献する.

二点目はスポット像の強度ピーク位置, 寸なわち光 軸中心同定の精度と安定性の向上である。本手法では 距離の離れたスポット像を二枚以上用いる必要がある が，光軸中心の同定精度と安定性の向上は二面閒の位 置関係の安定性に繋がり，本手法の向上に繫がる. 図 1 下図において，测定画像は強度ピーク付近が丸め䛊差 やブルーミングなどの CCD 特性によって平坦化され てしまっているが, 本ローパスフィル夕適用後はピー ク位置が明確であり，CCD 1 セルの分解能で判別で きるようになる。
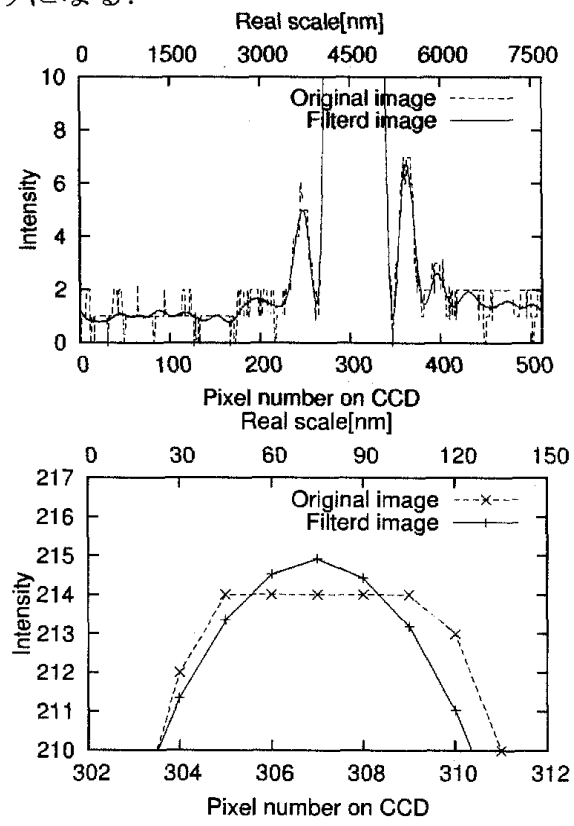

Fig. 1 The low-pass filtered DVD spot intensity distribution captured with 8 bit CCD

2.4.2 バックグラウンドレベルを末知数とした評価

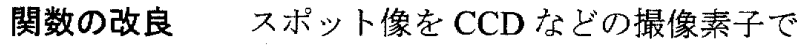
撮影した場合，強度分布にオフセットが乗り誤差の原 因となる：この問題を克服するために，評価関数を次 式の様にし， BG(バックグラウンドレベル) 值も未知 数とする.これにより， BG 值を CCD1 階調分以下の 分解能で求めることができ，解の精度と安定性が大き く向上する. ここで, $P(B G)$ は $\mathrm{BG}$ 值がある程度の範 
囲に入るようにするためのペナルティ項である.

$\sum_{i}\left\|\left[\boldsymbol{W}_{i}\right]\left(\left|\left[\boldsymbol{A}_{\boldsymbol{i}}\right]\{K\}\right|^{2}-\left|\left\{\overline{\boldsymbol{f}_{i}}\right\}\right|^{2}+B G\right)\right\|^{2}+P(B G) \rightarrow \min$

これらの改良により，解の精度・安定性は十分高まる。 しかしもし安定性が不足していると思われる場合は， Tikhonovの手法 ${ }^{(17)}$ を用いて評価関数に $w \|\{K\}||^{2}(w$ は 重み值) という制約項を加えることも有効である。

\section{3. 数 值 実 験}

$3 \cdot 1$ 数值解析例と手法の改良点の評価 数值実 験により本手法の有効性，ならびに本手法の改良点 の有效性の検証を行う。解析対象は実際の DVD ピッ クアップを想定し， $\lambda=650[\mathrm{~nm}], \mathrm{NA}=0.6$ とする. 正 解のスポット像の空間スペクトルの強度分布は一様と し，波面収差として収差係数のうち五次収差までのも の $\left(z_{1} \sim z_{15}\right)$ に值を与えた. 用いるデフォーカス面は一 $1300[\mathrm{~nm}]$ と $600[\mathrm{~nm}]$ の二枚とし, 同じ感度, 露光時閒 (等スケール)で撮影したものとする，解析領域は一次 リングをおおよそカバーできる $2400[\mathrm{~nm}] \times 2400[\mathrm{~nm}]$ の領域とし，これを $41 \times 41$ 点に離散化する。これら の量より仮想的に撮影したスポット像を作成する. 像 の作成の際には 256 諧調 (8bit) の CCD で撮影すること を想定し，以下の手順でノイズを与える．始めに \pm 0.5 諧調の範囲でのランダムノイズを与える. 次に+0.2 諧 調分のバックグラウンドレベルのオフセットを与える. 最後に像を 256 諧調に丸める。 また，本手法の重み行 列 $\left[\boldsymbol{W}_{\boldsymbol{i}}\right]$ の $\mathrm{M}$ 行 $\mathrm{N}$ 列成分 $W_{i}^{M N}$ は著者らの経験に基づ き以下のように設定する.ただし, $\left|\overline{f_{i}^{M}}\right|^{2}$ は $\left|\overline{f_{i}}\right|^{2} の \mathrm{M}$ 番目成分とする.

$$
W_{i}^{M N}= \begin{cases}1 / \sqrt{\left|\overline{f_{i}^{M}}\right|^{2}}= & (M=N) \\ 0 & (M \neq N)\end{cases}
$$

本手法の未知量は $\alpha_{n}^{m}$ の低次の 15 項, $\beta_{n}^{m}$ の低次の 16 項する．2.4 節の改良点の効果を確認するために, 以下の 4 つのケースで解析を害行する.

- CaseA: BG 值は未知数よしない、ローパスフィル 夕を用いない。

- CaseB: BG 值は未知数としない。ローパスフィル 夕を用いる。

- CaseC: BG 值は未知数とする. ローパスフィルタ を用いない。

- CaseD: BG 值は未知数とする.ローパスフィルタ を用いる。

正解の収差係数と各ケースの解析結果を図 2 の左に, 正解との誤差量を図 2 の右に示寸。
二点の改良点を適用していない本手法を用いた caseA でもまずまずの結果が得られた，さらに，各改良点が 精度の向上に効果的に機能していることが確認された。 また，二点の改良点を両方適用した caseD では全部の 収差係数の誤差が $0.54[\mathrm{~m} \lambda]$ 以下に抑えられている.

\section{2 空間スペクトルの強度分布が大きく变化する} 場合の解析例 前節では空間スペクトルの強度分布 が一様であると仮定した．本節ではこれに大きな分布 があるものを解析詨象とした場合の本手法の有效性を 検証寸る．空間スペクトルの強度分布以外の解析条件 は前節と同様とする.

仮定した強度分布を図 3 に，正解の収差係数と本手 法での解析結果を図 4 の左に，解析の誤差量を図 4 の 右に示す．空間スペクトルの強度分布に変化がある場 合でも十分な精度で解析できることが確認された。
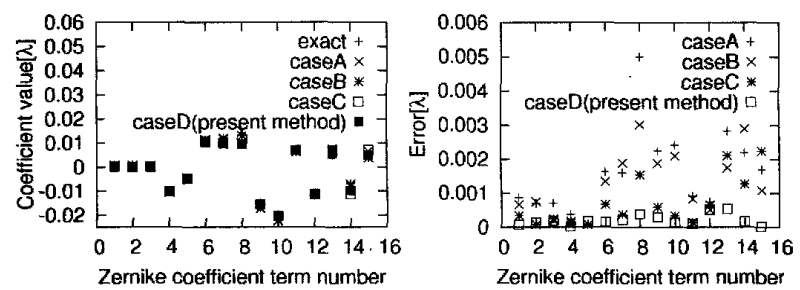

Fig. 2 Result of numerical experiment (Intensity distribution of spectrum is constant)

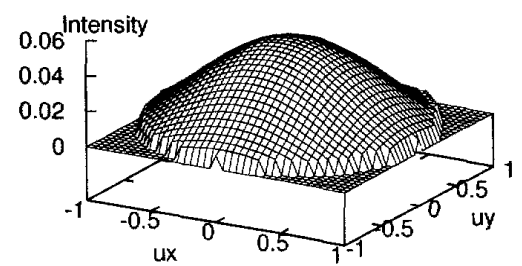

Fig. 3 Power spectrum
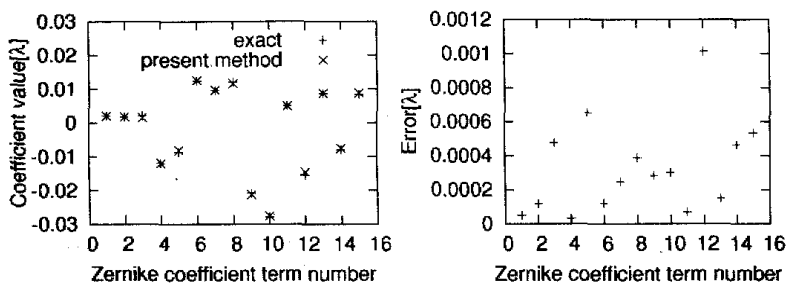

Fig. 4 Result of numerical experiment (Intensity distribution of spectrum is variable slope)

\section{4. 本手法による解析例}

4.1 実験条件実験装置の模式図および写真を 図 5 に示寸。光学系は倍率 500 倍の顕微鏡光学系と なっている. 対物レンズはピエゾ素子 (分解能 $10[\mathrm{~nm}]$ ) に取り付けられており，この電圧を制御することで任 意のデフォーカス面のスポット像を撮影できる．像は 
CCD で 256 階調 (8bit) で撮影することができる．対物 レンズと測定対象の光ピックアップの閒には DVDの ディスクの設計值と同じである嬮み $600[\mu \mathrm{m}]$, 屈折率 1.52 のガラス板 (BK7) が抙入されている.

測定対象は $\mathrm{NA}=0.55$, 波長 $650[\mathrm{~nm}]$ の DVD ピック アップ用対物レンズである. 撮影したスポット像のデ フォーカス距離は- $1300[\mathrm{~nm}]$ と，600[nm] である.こ れらは全て同じ露光時間で撮影し， 2.4.1 節のローパ スフィルタを施している. デフォーカス距離の設定精 度はピエゾの分解能と同值の $10[\mathrm{~nm}]$ 程と考えられる. 解析領域は一次りングをカバーできる約 $2400[\mathrm{~nm}] \times$ $2400[\mathrm{~nm}]$ の領域とし，これを $41 \times 41$ 点に離散化し て切り出した．測定した強度分布の平方根分布 (振幅 分布) を図 7 に示す. 本手法の末知数は $\alpha_{n}^{m}$ の低次の 8 個, 虚部 $\left(\beta_{n}^{m}\right)$ の低次の 8 個, BG 值の計 17 個とする. また, 本手法の重み行列 $\left[\boldsymbol{W}_{i}\right]$ の作成方法は第 3 節と 同様とする.
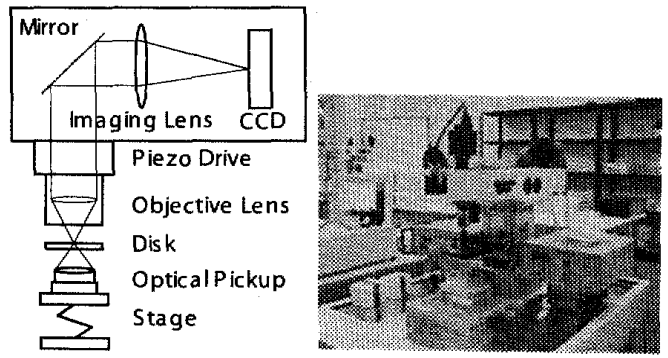

Fig. 5 Measurement system

4.2 実験結果得られた収差倸数 $z_{k}$ と本計測を 10 回繰り返して得られた結果の標準偏差を図 6 に示 す. 収差係数の同定結果の標準偏差は十分小さかった. 特に評価の指標として重要な $z_{4}$ 以降の係数は標準偏差 で $0.001[\lambda]$ のばらつきであり,. 実用上十分な繰り返 し精度で解析できた. また, 収束時の| $\mid \boldsymbol{A}]\{K\} \mid$ の分布 を図 8 に, 得られた解より推測されるフォーカス面の 空間周波数分布 (強度分布 $\left|\boldsymbol{g}^{*}\right|^{2}$ と波面収差 $\boldsymbol{\phi}$ ) を図 9 に示す．二枚のデフォーカス像のどちらも分布全体に わたりよく収束している.さらに，本手法により推測 された空間スペクトルの強度分布と実際の射出睲の強 度分布を実測したものとの比較を行った. その結果を 図 10 に示す. 両者は良く合致していることが確認さ れた：測定時閒は像の撮影に $0.2[\mathrm{sec}$ ], 演算に $0.3[\mathrm{sec}]$ の計 $0.5[\mathrm{sec}]$ と十分高速であった. 尚解析用の PC の スペックは, CPUが Pentium Core2Duo 2.6GHz, メイ ンメモリが 2GB，となっている．また，数值計算ライ ブラリに IntelMathKernelLibrary9.0を，コンパイラに 汒 IntelC++Compiler9.0を用いて扝り，IntelCore2Duo に最適コンパイルを行った. 尚, 行列 $[\boldsymbol{A}]$ を二つ作成
するのに要した時間は $2.0[\mathrm{sec}]$ 程であった。

\section{3 スポット像の位置決め精度と測定精度に関する}

補足本実験結果において, $z_{1}, z_{2}$ は他の収差係数に 比べて測定結果の標準偏差が大きい. スポット像の光 軸中心は強度ピークのXY位置であるが，この位置の 測定分解能が $z_{1}, z_{2}$ の標準偏差に現れていると考えられ

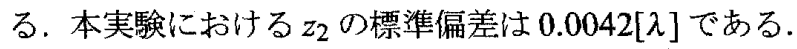
これをフォーカス面上での位置ずれ量に換算すると， $0.0042[\lambda] * \frac{\lambda}{\mathrm{NA}}=4.96[\mathrm{~nm}]$ となる. さらに, 実験装置の 光学倍率が 500 倍なので, $\mathrm{CCD}$ 上での位置ずれ量の標 準偏差 $\sigma_{x y}$ は $2.48[\mu \mathrm{m}]$ ，そして $3 \sigma_{x y}$ は $7.45[\mu \mathrm{m}]$ とな る.この值は CCDの 1 セルの一辺の大きさ $7.40[\mu \mathrm{m}]$ とほぼ同值である。この精度はローパスフィルタによ り強度ピークの同定精度が CCD 1 セルの分解能で得 られることに起因していると考えられる.

$z_{1}, z_{2}$ に次いで測定結果の標準偏差が大きいのは $z_{3}$ である.これは一般にデフォーカス項と呼ばれており， その同定精度はフォ一カス面のZ方向の位置決め精 度に起因している．本実験における $z_{3}$ の標準偏差は 0.0016[入]であり，これをZ方向の位置のずれ量の標準 偏差 $\sigma_{z}$ に換算すると, $\sigma_{z}=0.0016[\lambda] * \frac{4 \lambda}{\mathrm{NA}^{2}}=13.8[\mathrm{~nm}]$ となり， $3 \sigma_{z}=41.4[\mathrm{~nm}]$ となる.これはピエゾの分解能 である $10[\mathrm{~nm}]$ より大きく，测定時の振動などの影響 に起因していると推測される.

一方で，上記のフォーカス面のスポット像のXYの 位置ずれは理論的には $z_{1}, z_{2}$ のみにしか影響を与えな い.また，Z方向の位置ずれも理論的には $z_{3}$ 以外に はほとんど影響を与えない(この点に関する詳細は 5.1 節に示す). そのため, $z_{4}$ 以降の収差成分はスポット 像の位置決め誤差に対して安定な測定が可能である. また，レンズや光ピックアップの生産において評価さ れる収差は非点収差, コマ収差, 球面収差などの $z_{4}$ 以 降の係数であり， $z_{1} \sim z_{3}$ は注目されていない. 以上の ことから，本手法はスポット像の位置決めを多少粗く ても十分な解析が行える手法であると見なせる。これ は，スポット像の位置決めに大きな労力を要する干涉 計に対する本手法の優位性の一つと言える.

\section{5. 収差变化の理論予測との比較実験}

理論に基づく収差感度実験を行い，その収差変化量 の理論予測と実験結果の比較を行った。本節ではその 結果を示す，注目する収差量は，デフォーカス項 $\left(z_{3}\right)$ と三次収差であるコマ収差 $\left(z_{6}, z_{7}\right)$, 球面収差 $\left(z_{8}\right)$, 非 点収差 $\left(z_{4}, z_{5}\right)$ である.

実験の概念図を図 11 に示す。解析対象は $\lambda=$ $650[\mathrm{~nm}], \mathrm{NA}=0.635$ の DVD ピックアップを用いる. 

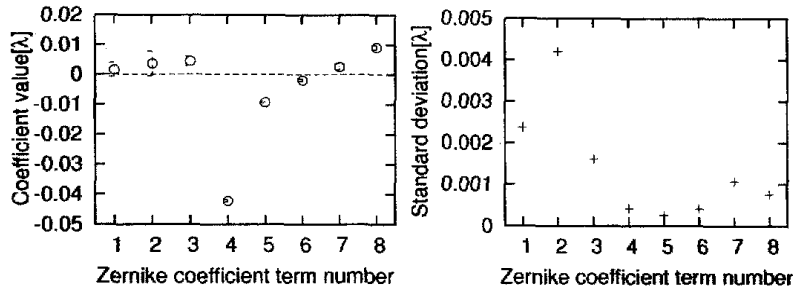

Fig. 6 Identified Zernike coefficients(left:identified value, right:standard deviation of identified value)
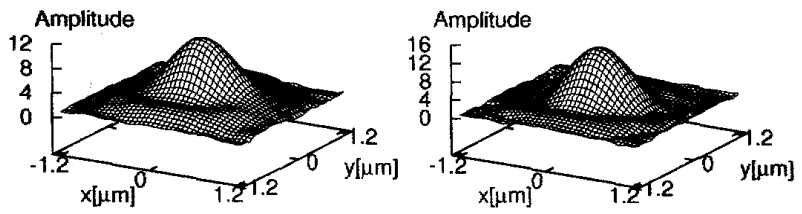

Fig. 7 Observed amplitude distribution on defocus plane (left:-1300[nm], right:600[nm])
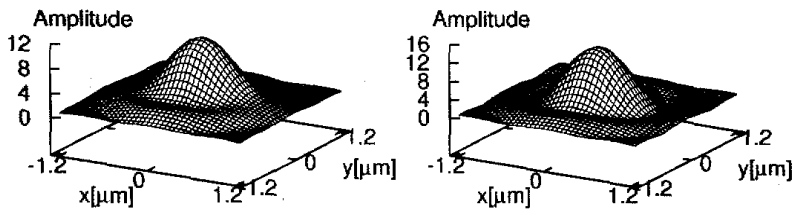

Fig. 8 Calculated amplitude distribution on defocus plane (left:- $1300[\mathrm{~nm}]$, right:600[nm])
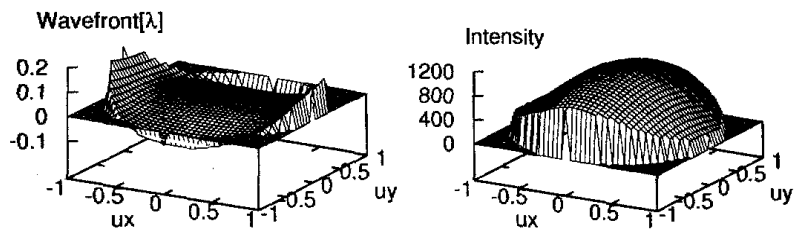

Fig. 9 Identified spectrum (left:Wavefront, right:Intensity distribution)
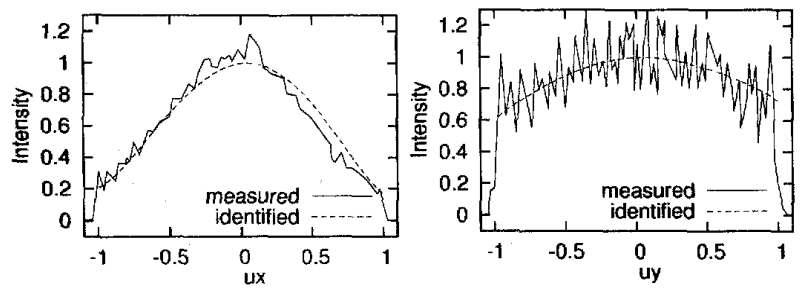

Fig. 10 Comparison between measured pupil intensity distribution and the one of identified spectrum (left:cross-section X, right:cross-section Y)

その他の条件や実験装置は 4 節と同じである.

5.1 光ピックアップの位置を乙方向に変化させた ときのデフォーカス項の変化 光ピックアップの

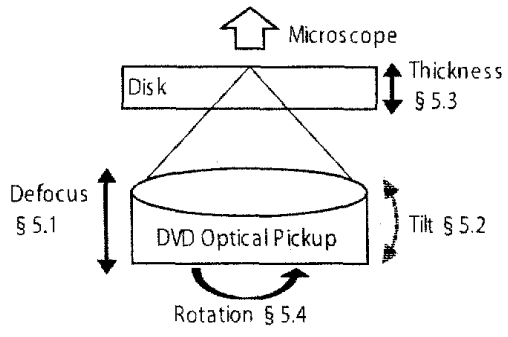

Fig. 11 Image of experiment using DVD optical pickup

位置を Z方向に変化させたとき (デフォーカスさせ たとき)の収差変化を測定する。フォーカス面に対 して 1 波長分 Z方向に動かしたときの波面収差の変 化量 $d \phi(u, \psi)$ は角度スペクトル伝播モデル ${ }^{(10)}$ より， $d \phi(u, \psi)=\sqrt{1-(\mathrm{N} A u)^{2}}$ と表せる。これは軸対象の 分布であるので, 収差係数の内の軸対象のモードの係 数のみが変化する. 特に大きく変化するのはデフオーカ 不係数と呼ばれる $z_{3}$ であり, 変化量 $d z_{3}(D)$ は Zernike 基底関数 $R_{3}(u, \psi)$ と $d \phi(u, \psi)$ との内積をとることに 上り求まる.これを $\left\langle R_{3} \cdot d \phi>\right.$ と表記すれば， $Z$ 方向 の移動量 $F$ に対する $z_{3}$ の変化量 $d z_{3}(F)$ は次式となる.

$$
d z_{3}(F)=F / \lambda \cdot\left\langle R_{3} \cdot d \phi\right\rangle
$$

非点収差 $\left(z_{4}, z_{5}\right)$ やコマ収差 $\left(z_{6}, z_{7}\right)$ 等の非軸対象の収 差成分は理論上一切変化しない.

解析対象のDVD ピックアップを用いた場合の理論式 (15) は $d z_{3}(F)=-0.1295[\lambda / \mu m] \cdot F$ となる. 始めにス ポットの強度ピークの位置を探し，おおよそのフォー カス面を探す.これを基準とし，デフォーカス量とし て-0.6[ $[\mu \mathrm{m}] \leq F \leq+0.6[\mu \mathrm{m}]$ の範囲内を $0.2[\mu \mathrm{m}]$ 置きに 動かし, 本手法で解析老行う。

本実験の結果と $z_{3}$ の回帰直線, 理論式 (15) のグ ラフを図 12 に示寸. フォーカス面の位置に対して, $z_{3}$ のみが大きく線形に変化した， $z_{3}$ の直線回帰式は $d z_{3}(F)=-0.1343[\lambda / \mu m] \cdot F+0.0002[\lambda]$ となり，回帰 直線と理論式 (15) の傾きの誤差は 3.7\%で支るため, 理論通りの結果が得られたと言える.フォーカス面の 位置と $z_{3}$ の直線回帰による相関係数も 0.997 と十分高 い.また，他の収差係数はほとんど変化しないという 理論通りの結果が得られた。本手法がフォーカス面の 位置決めに対してロバストな測定であることが言える.

5.2 光ピックアップを傾けたときのコマ収差変化 光ピックアップをディスクに対して傾けて収差解析を 行った場合の傾斜角度に対する三次コマ収差の変化を 測定する. 光ピックアップの X 方向一の傾き角度を $T$ とすると, 三次コマ収差係数 $z_{6}$ の $T$ に対する変化量 


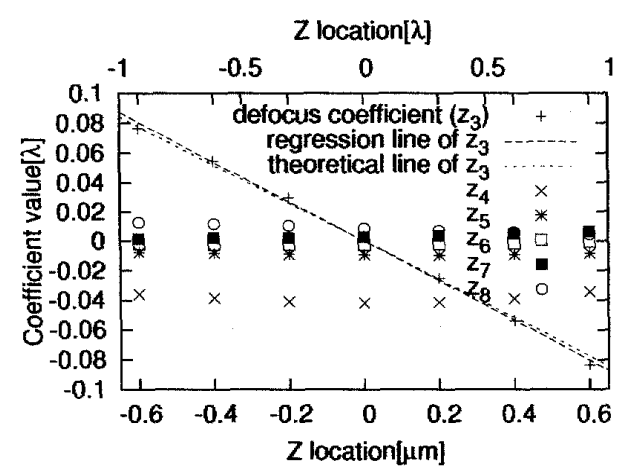

Fig. 12 Result of defocus experiment using DVD optical pickup

$d z_{6}(T)$ の理論式は次式となる ${ }^{(18)}$.

$$
d z_{6}(T)=-T\left(D / \lambda \cdot \operatorname{asin}^{3}(\mathrm{NA})\left(\frac{N^{2}-1}{6 N^{3}}\right)+C_{d e v}\right)
$$

ここで, $C_{d e v}$ は測定装置側, 特に対物レンズへのスポッ 卜像の入射角度によって発生するコマ収差の比例係数 であり，対物レンズの設計によって決定される． $C_{d e v}$ より手前の項はディスクへの入射角度によるコマ収差 への影響を表している. コマ収差への影響の大きさは ディスクによるものの方が压倒的に大きいが， $C_{d e v}$ の 影響は無視できるものではない.

解析対象のDVD ピックアップを用いた場合の理論式 (16) は $d z_{6}(T)=\left(-14.70[\lambda / \mathrm{rad}]+C_{d e v}\right) T$ となる. 実 験の傾け量は X 方向に- $10[\mathrm{~min}] \leq T \leq 10[\mathrm{~min}]$ の範囲 内で $5[\mathrm{~min}]$ 刻みに動かす。

本実験による結果とその回帰直線， $C_{d e v}=0$ とした場 合の理論式(16)のグラフを図 13 に示寸. 理論通りの結 果が得られた. 直線の回帰式は $y=-15.26[\lambda / \mathrm{rad}] T+$ $0.00304[\lambda]$ となり，回帰直線と理論式 (16) の傾きの誤 差は $11 \%$ であるため， $C_{d e v}$ の影響が含まれていると 考えられる．また，傾け量と $z_{6}$ の直線回帰による相 関係数は 1.000 と十分高い值が得られた。

\section{3 ディスクの厚みを変化させた時の球面収差変} 化実験装置の対物レンズに張られているディスク の厚みを変化させたときの, 厚み変化量に対する三次 球面収差の変化を測定する.ディスクの厚み $D$ の設計 值からの差分量を $d D$ としたとき，三次球面収差計数 $z_{8}$ の $d D$ に対する変化量 $d z_{8}(d D)$ の理論式は次式とな $ろ^{(18)}$.

$$
d z_{8}(d D)=-\frac{d D / \lambda \cdot \operatorname{asin}^{4}(\mathrm{NA})\left(N^{2}-1\right)}{48 N^{3}}
$$

解析対象のDVD ピックアップを用いた場合の理論 式 $(17)$ は $d z_{8}(d D)=-0.00268[\lambda / \mu m] \cdot d D$ となる. ゙゙

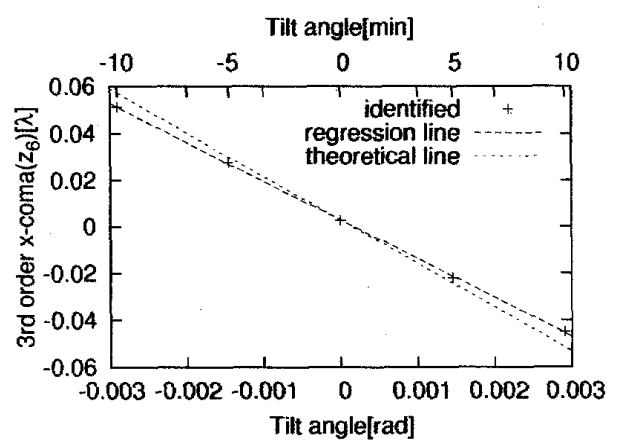

Fig. 13 Third order coma change for tilting a DVD optical pickup

イスクの厚みは $570[\mu \mathrm{m}] \leq d D \leq 620[\mu \mathrm{m}]$ の範囲内で $10[\mu \mathrm{m}]$ ずつ変化させる.

本実験による結果とその回帰直線，理論式 (17) の グラフを図 14 に示す. 横軸はディスクの設計值であ る $600[\mu \mathrm{m}]$ からの差をとっている．直線の回㷌式は $d z_{8}(d D)=-0.00265[\lambda / \mu m] \cdot d D+0.00364[\lambda]$ となり, 回帰直線と理論式 (17) の傾きの誤差は 1.1\%であるた め，理論通りの結果が得られたと言える。また，ディ スクの厚みと $z_{8}$ の直線回帰による相関係数は 0.999 と 十分高い值が得られた。

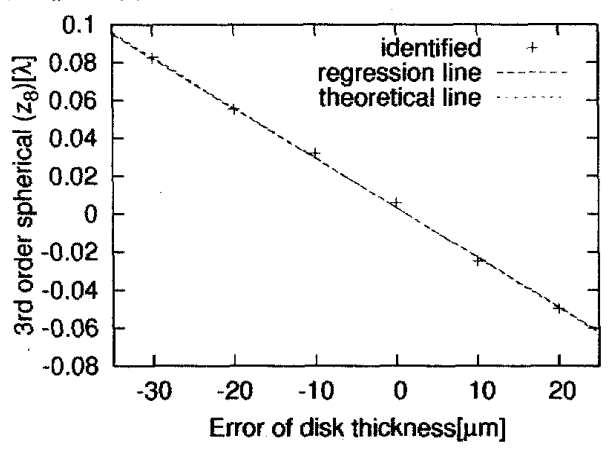

Fig. 14 Third order spherical change for error of disk thickness using DVD optical pickup

5.4 光ピックアップを光軸周りで回転させたときの 非点収差変化 光ピックアップを光軸周りで回転さ せた時の三次非点収差 $\left(z_{4}, z_{5}\right)$ の変化を測定する. 横軸 に回転量，縦軸に収差量としたとき，理論上，どちら も同じ振幅と周期 $(180[\mathrm{deg}])$ のサインカーブとなり， 位相差が $45[\mathrm{deg}]$ となる. その振幅が光ピックアップ に含まれる非点収差量となり，平均值が装置側となる。

本害験では光ピックアップを $0[\mathrm{deg}]$ 360[deg] の範 囲内を 30[deg] 刻みで回転させた．実験結果とそれを サインカーブに回㷌したグラフを図 15 に示す. $z_{4}, z_{5}$ の

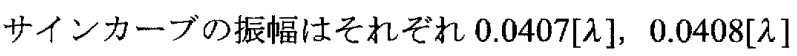


と両者の振幅の誤差は $0.25 \%$ と十分小さい. また位相 差も 44.8[deg] となったため, 理論通りの結果が得ら れていると言える. 測定器側の非点収差も $0.009[\lambda]$ 程 とわかる.また，回転量と $z_{4}, z_{5}$ のサインカーブ回帰 による相関係数はどちらも 0.999 と十分高い值が得ら れた。

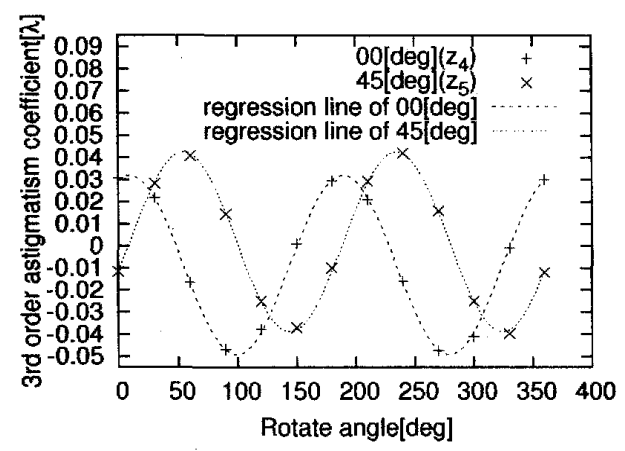

Fig. 15 Third order astigmatism change for rotating a DVD optical pickup

\section{6. 結 言}

従来の収束型の位相回復法を基礎として実用的に用 いることができるスポット像からの波面収差解析手法 を開発した。 また，撮像素子の各種ノイズに対するロ バスト性を向上させるための改良を本手法に施し，上 り実用に耐えうる手法とした，数值実験を行い，本手 法が実用上十分な性能を持っている手法であることを 示した. 本手法で実際のDVD ピックアップの収差解 析を行い，その波面収差を $0.5[\mathrm{sec}]$ で同定した。また， 本手法が収差係数を $\pm 0.001[\lambda]$ の繰り返し精度で得ら れる手法であることを実証した．実際の DVD ピック アップを対象に理論と比較する複数の検証実験を行い, その結果から本手法の精度を定量的に評価できた．各 実験結果において，入力パラメータと測定結果との閒 での相関係数はきわめて高い值が得られたともに, 測 定結果が十分な理論との整合性が得られた. 以上によ り，本収差解析手法は実用的であり高精度な収差解析 が可能であることが実証された.

本論文における重み行列の決定方法やデフォーカス 距離の選定方法は, 筆者らの経験に基づく所が大きい. 今後の課題はこれらの要素を適切に設定する方法の確 立であると考えている.

\section{文献}

(1) Motohiro Takada, "Laser aberration measurement using interferometer (in Japanese)", Optical alliance 2, (2001) 19-22
(2) Yasuhiro Tanaka and Motonobu Yoshikawa,"Novel measuring technique of the optical performance of objective lenses for optical disk systems", Applied Optics, 31, 25 (1992) 5305-5311

(3) R.W.Gerchberg and W.O.Saxton, "A practical algorithm for the determination of phase from image and diffraction plane pictures", Optik, 35, 2 (1972) 237-246

(4) J.R.Fienup,"Phase retrieval algorithms : a comparison", Applied Optics, 21, 15 (1982) 2758-2769

(5) D.L.Misell,"An examination of an iterative method for the solution of the phase problem in optics and electron optics: I. Test calculations", J. Phys. D: Appl. Phys., 6, (1973) 2200-2217

(6) Max Born and Emil Wolf, "Principles of Optics", Pergamon Press (1974)

(7) J.R.Fienup, "Phase-retrieval algorithms for a complicated optical system", Applied Optics, 32, 10 (1993) 1737-1746

(8) G.R.Brady and J.R.Fienup "Measurement of an Optical Surface using Phase Retrieval", 2006 Topical Meeting on Optical Fabrication and Testing (2006)

(9) Peter Dirksen,Joseph Brast, et al, "Aberration retrieval using the extended Nijboer-Zernike approach", J.Microlith.,Microfab.,Microsyst., Vol.2 No.1 (2003) 6168

(10) Earl G. Williams, "Fourier Acoustics: Sound Radiation and Nearfield Acoustical Holography ", Springer-Verlag Tokyo (2005)

(11) Hiroshi Yabe and Naomichi Yamaki., "Nonlinear programming (in Japanese)", Asakura shoten (1999)

(12) Chris A.Mack, "Inside PROLTH:A Comprehensive Guide to Optical Lithography Simulation", FINLE Technologies(1997)

(13) Netlib Repository at UTK and ORNL. "BLAS (Basic Linear Algebra Subprograms)". NETLIB. (online), available from $<\mathrm{http}: / \mathrm{www}$.netlib.org/blas $>$, (accessed 2008-05-16).

(14) Netlib Repository at UTK and ORNL. "LAPACK Linear Algebra PACKage” . NETLIB. (online), available from < http://www.netlib.org/lapack $>$, (accessed 200805-16).

(15) OpenMP.org, "The OpenMP API specification for parallel programming " . OpenMP.org. (online), available from < http://openmp.org/wp/>, (accessed 2008-05-16).

(16) Masato Shibuya and Hiroshi Oki., "Optical library 1: Optics about diffraction and imaging (in Japanese)", Asakura shoten (2005)

(17) Shirou Kubo, "Series of Computational Mechanics and CAE 10: Inverse Problem (in Japanese)", Baifukan Co., Ltd (1992)

(18) James C. Wyant, "Basic Wavefront Aberration Theory for Optical Metrology", Applied Optics and Optical Engineering, Vol. Xl (1992) 